\title{
The Impacts of Permendag NO. 21/M-DAG/PER/10/2005 on the Structure, Conduct, and Performance of Motorcycle Industry in Indonesia
}

\author{
Aleknaek Martua Nababan \\ Master in Planning and Public Policy \\ University of Indonesia \\ Jakarta, Indonesia \\ aleknaeknababan@gmail.com
}

\author{
Ashintya Damayati \\ Master in Planning and Public Policy \\ University of Indonesia \\ Jakarta, Indonesia \\ ashintyad@gmail.com
}

\begin{abstract}
This research analyzes the responses of firms to the oligopoly motorcycle industry after Permendag No.21/MDAG /PER/10/2005 (Permendag No.21 / 2005 in 2005) on structure, conduct, and performance. Price cost margin ratio represents as performance; advertising and $R \& D$ expenditure ratio as conduct; and concentration ratio as structure in the motorcycle industry during the $2001-2014$ period, which and are distinguished based on the size of the firms. This study applies simultaneous equation system model, and the Two Stage Least Square (TSLS) for the parameter estimation. The empirical result shows that the impacts of permendag regulation as exogenous variable to $\mathrm{CR} 2$ growth can reduce the competition in motorcycle industry. Foreign direct investment as foreign shareholder of the firm negatively impacts on the conduct of firms because no company owns a central of $R \& D$ in Indonesia. On the performance, efficiency impacts positively on the price cost margin. The other variables on performance, concentration ratio and growth industry interaction have positive impacts on price cost margin. It describes that the ease of collusion of motorcycle industry in Indonesia can increase performance on price cost margin.
\end{abstract}

Keywords- Permendag No.21/2005; Motorcycle Industry; Oligopoly; $S C P$

\section{INTRODUCTION (HEADING 1)}

Motorcycles is one of the most popular means of transportation for the Indonesian people. The price of motorcycle is affordable enough to purchase by the the middle to lower class communities. The demand for motorcycle is increasing as time goes by. The average growth of motorcycle demand reached $12 \%$ since 2009 - 2014. This growth is the highest compared to other means of transportation. It proves that motorcycle is a more desirable transportation in the Indonesian community.

Motorcycle industry plays an important role for the economy in Indonesia. According to Haryotejo (2006), the automotive industry is the main industry supported by the government since the era of industrialization. This is because this industry has multiplier effects on the upstream industry as a provider of raw materials for the manufacture of motorcycles and others; While in the downstream industry, the product can be used to support the economic activities and add economic value. The motorcycle industry can absorb a considerable amount of labor and provide a positive experience in the use of modern technology (Atmodjo, 1997).

The competition in motorcycle industry is attractive for companies in Indonesia since the demand of motorcycles in the period of 2001 - 2014 was still at the growing stage and the ratio of population to motorcycles was relatively low. This is supported by the growth of population and relatively high economic growth during that period. However, in 2005 the market shares of motorcycles were dominated by companies joining the AISI memberships. In 2003, AISI member companies accounted for $91.3 \%$ of the market shares. Around the year 2004 - 2005, from 77 assembling, manufacturing and importer companies in Indonesia, only seven companies were listed in Deperindag as AISI members and seventy companies were not registered as AISI members. This reflects the low competition of motorcycle industry in Indonesia.

Pradiptyo (1996) stated that the government contributed to create an oligopolistic industrial structure. This happened due to the issuance of Decree of the Minister of Trade and Cooperation No. 75 / KP / I / 83 by the Minister of Trade and Cooperatives. The existence of the government in 1983 has legitimized the existence of associations for businessmen and businesspersons of the real sectors. The decree stated that the business is obliged to join the membership of industry sector associations. The decree has indirectly supported the coordination efforts of companies engaged in the same sectors and products and has the potential to create collusion. The existence of an association basically allows for entrepreneurs to gather, coordinate, and form marketing deals in order to gain higher profits (Setiawan, 2006). This is supported by the statement of the Enforcemenet Director of KPPU, Gopprera Panggabean, on the field trip of MPKP UI to KPPU in May 2017, who stated that the problems faced by unhealthy business competition were about 30 - $40 \%$ involving associations in the meetings and coordinations.

In 2005, the Minister of Trade issued a regulation through the Permendag No.21 / 2005 on the revocation of several licenses and trade association registrations. The regulation has 
revoked and declared the non-enactment of Decree of the Minister of Trade and Cooperation No.75 / KP / I / 83 of 1983 on compulsory registration for trade / association business organizations in Indonesia. The policy does not require companies to be registered as members of the association; it is expected to minimize the unfair business competition started from the meetings and coordinations held by the associations. This is beyond expectations, because in 2014 the members of the motorcycle industry associations were getting smaller. But most shareholders of a large market share were still listed as members of AISI. The Honda, Yamaha, Suzuki, and Kawasaki brand companies controlled $99.7 \%$ of the motorcycle market shares in Indonesia and were still incorporated in AISI until the end of 2014. The fewer members enrolled in AISI with a very high share of the motorcycle market share, the risk of coordinations and unfair business competition is higher.

Based on the background above, this study is aimed to analyze the impacts of the Permendag No.21 / 2005 policy of 2005 on the structure, conduct, and performance of motorcycle industry in Indonesia by applying the SCP paradigm. To achieve that main goal, this research will analyze the effects of the structure on the behavior and performance, the effects of behavior on the structure and performance, and the effects of performance on the structure and behavior of motorcycle industry in Indonesia.

\section{LITERATURE REVIEW}

\section{A. Structure-Conduct-Performance}

The theory of SCP is applied in this study to find the relationships between structure, conduct, and performance that affect each other and ascertain the impacts of the government intervention through regulations issued.

According to Clarke (2003), the structure of a market is a pattern in which elements in an industry are interrelated because of interactions between the sellers, between buyers, between sellers and buyers, or between old sellers and prospective sellers joining the competition, and the government's policies that affect it. Arsyad and Kusuma (2014) stated that the SCP is a classic approach in industrial economics and a benchmark for the development of various approaches in the industrial economy.

The concentration ratio of two firms is used in this study to measure the size of the market structure $\left(\mathrm{CR}_{2}\right)$. Baye $(2010)$ explained that the behavior of an industry refers to how a company in an industry behaves in a market. The decisions of a company in the conduct include pricing, advertising, investments in research and development activities, and other decisions within the company. The variable of conduct is the combination of $\mathrm{R} \& \mathrm{D}$ and advertising costs at a company scale. PCM is used in the company performance variable, to measure the ratio of profit cost to input.

The research model in this study refers to Strickland and Weiss (1976), Martin (1979), Yucheng et al.(2015), and Farber (1981). Martin (1979) said that the price increases because deals are easier to do when many sellers get less standardized products and transparent product price transactions on the market. In the case study of Binger et al.(1992) in Martin (1979), the average output for cournot market experiments explained that fewer sellers in a group created greater potential collusion than more sellers. Communication between sellers also gave an impact on the company's output settings. Experiments proved that sellers who communicate in one group produced the same amount of output. This is similar to the principle of collusion; when sellers communicate to each other to coordinate the set output, it affects the selling price in the market. The impacts of collusion on the market are not only related to the increasing price, but also how long the increase can be maintained by the existence of the agreement. The impact of collusion on performance is the increase of the price percentage on the marginal cost of a company. This makes the market power of a company higher due to the greater price of marginal cost. While the impact of collusion on the market structure is the obstacles for prospective new entrants to enter the market in the industry.

Strickland and Weiss (1976) assumed a lot of researches used models with regression analysis and ordinary least square estimation on the relationships of single equations. A research tends to be wrong if describing relationship as a system of simultaneous equations. So in this study, a simultaneous equations system modelling is used to explain the relationships between behavioral and performance structures.

\section{B. Variables Specifications}

In the Strickland and Weiss (1976) models referring to Dorfman and Steiner (1954), it was clear that the optimal level of corporate advertising spending would occur when the marginal revenue of a product advertisement equals to the absolute value of the demand elasticity of the firm's products. When the price elasticity of the demand curve faced by the firm was low in the concentrated industry, then the intensity of the advertisement might be expected to increase along with the concentration. The choice of exogenous variables affecting the variable price cost margin was the growth of demand.

Advertising which initially increased with concentration, would drop along with the high concentrations due to collusion made to avoid advertising. This affected the model; the variables influencing the advertising are $\mathrm{C}$ with a positive sign and $\mathrm{C} 2$ with a negative sign. In influencing the effectiveness of advertising, a very important variable is the share of total sales received by consumers CD / S. The effect of advertising on concentration shows that the economic scale in advertising was large. On the other hand the effect of advertising on margin was slightly greater than expected; that advertising costs were included in the price cost margin so that it was not significant in the consumer goods industry.

Based on Strickland and Weiss (1976) research models, the CR4 and GD variables were illustrated ease to collusion. The variables included in the barrier of entry (MES / S and A / S) indicated natural entry conditions. Measuring profitability used price cost margin; the ratio of sales capital must exist to obtain capital gains in normal limits. Martin (1979) in the model added foreign supplier variables (IM / S) as exogenous variables that could affect profitability. The strong IM / S would increase the price demand elasticity of domestic 
supplier. Lustgarden (1975) found a significant relationship to estimate the concentration ratio of four buyer companies in explaining profitability. Strickland and Weiss (1976) included the ratio of sales to advertising in profitability equation as an entry barrier from product differentiation. The concentration on the model adopted from Gaskins (1971) which was a profit maximization model showed that the entry rate was related to market differences and price limits. In adopting the model of advertising, Martin (1979) followed the Dorfman-Steiner model where the advertising sales ratio would be equal to the price cost of the product margin multiplied by the demand advertising elasticity.

Yucheng et al.(2015), described the causality relationships formed between advertising, concentration, and performance. The model in their study explained that in the equation formed there was a relationship affecting each other; between the ads, concentration, and performance. The results of the study explained the increase in the intensity of advertising did not significantly affect the increase of market share for middle and upper classes, in liquor companies. It also found that a high concentration ratio encouraged companies to invest more in advertising costs.

Research by Farber (1981) focused on the relationships of market structures and corporate incentives to develop and innovate, as the impacts of structures from the supply side of the market. The hypothesis in the study was made as a theoretical refinement and empirical test on the relationships between research and development activities (R \& D) and supply-side characteristics such as concentration, firm size, and diversification. Farber (1981) exposed that innovations of a product are also a form of competition, as well as price and advertising factors that are influenced by both the buyer structure and the structure of the seller in the market. Inventions and innovations made by a company will create new production process and products. The new process will automatically result lower production costs for input suppliers and possibly more efficient new products as inputs to consumers. The new products will generally have a cost impact and demand effect to buyers. Any discovery and innovation will affect the cost cutting or increase the buyers' demand. The study explained that a collusive monopoly and oligopoly company will choose the rate of profit by maximizing the price level, cost of sales, and R \& D activities. The partially adopted model of Demsetz said that monopoly market structure would potentially higher the $\mathrm{R} \& \mathrm{D}$ cost savings. The study also argued that the increase of market concentration could hamper the increase of $\mathrm{R} \& \mathrm{D}$ activities and on the contrary, the R \& D activities tended to improve when markets were more competitive.

\section{RESEARCH METHODOLOGY}

The specific companies discussed in this research are large medium-sized enterprises that produce two-and three-wheeled vehicles. This study aims to determine the impacts of the deregulation of the entrepreneur's duty to join the Indonesian Motorcycle Industry Association (AISI) on the structure, behavior and performance of each company that produces two and three-wheeled motorcycles, in Indonesia. The model used to answer this study refers to the Strickland and Weiss (1976) and Martin (1979) models. The model explains the existence of simultaneous relationships that affect each other between structure, conduct, and performance. Strickland and Weiss (1976) and Martin (1979) used industry as their unit of analysis; while this study used data plant as its unit of analysis because the industry discussed in this study was specific to large medium-sized industries producing two and three wheeled motor vehicles.

The data sources in this study are secondary data provided by the Motorcycle Industry Association (AISI) and the annual survey conducted by BPS to the large medium-sized industries. Secondary data obtained from AISI include market share data from each company in 2001 - 2014. The secondary data of BPS in this study is sourced from annual survey results for ISIC 35911 in 2001 - 2009 and ISIC 30911 in 2010 - 2014. This data are unbalanced because not all plants exist in the span time of 2001 - 2014. Based on the explanation above, the model used in this study is as follows :

$$
\begin{aligned}
C R 2_{i j}= & a_{0}+a_{1} C R 2_{i j(t-1)}+a_{2} A R S_{i j}+a_{3} A R S_{i j(t-1)} \\
& +a_{4} M E S_{i j}+a_{5} M E S_{i j(t-1)}+a_{6} C D R_{i j} \\
& +a_{7} F D I_{i j}+a_{8} G P_{i j}+a_{9} D K_{i j}+a_{10} X_{i}+a_{11} Y_{i}+e_{i j}
\end{aligned}
$$

$$
\begin{aligned}
A R S_{i j}= & b_{0}+b_{1} P C M_{i j(t-1)}+b_{2} C R 2_{i j}+b_{3} C R 2^{2}{ }_{i j} \\
& +b_{4} I M S_{i j}+b_{5} G R_{i j}+b_{6} G P_{i j}+b_{7} F D I_{i j} \\
& +b_{8} D K_{i j}+b_{9} X_{i}+b_{10} Y_{i}+e_{i j}
\end{aligned}
$$

$$
\begin{aligned}
P C M_{i j}= & c_{0}+c_{1} C R 2_{i j}+c_{2} C R 2_{i j(t-1)}+c_{3} A R S_{i j} \\
& +c_{4} A R S_{i j(t-1)}+c_{5} C D R_{i j}+c_{6} C D R_{i j(t-1)}+c_{7} G R_{i j} \\
& +c_{8} G R_{i j} \times C R 2_{i j}+c_{9} I M S_{i j}+c_{10} K S_{i j} \\
& +c_{11} E F F_{i j}+c_{12} M E S_{i j}+c_{13} E K S_{i j}+c_{14} G E O_{i j} \\
& +c_{15} F D I_{i j}+c_{16} D K_{i j}+c_{17} X_{i}+c_{18} Y_{i}+e_{i j}
\end{aligned}
$$

This research linked between the structure, conduct, and performance at firm level. The model used several dependent variables and independent variables. In model structure, CR2 is a combination of two largest company concentrations. ARS described the ratio of advertising and $R \& D$ costs to total sales of company. This is because the variables available in the secondary data were other costs, which included advertising and $\mathrm{R} \& \mathrm{D}$ expenses. Other costs in the motorcycle industry are mostly advertising and $\mathrm{R} \& \mathrm{D}$ expenses. So all variables associated with advertising and R\&D were combined and included to other cost variables in each company. EFF described how the company could add value to their inputs. Efficiency was included in PCM equation model due to the 
condition of motorcycle industry in Indonesia which is full of technology. Cost efficiency could differ profits within the company. If the company had good management and technology, then the company would achieve efficient scale from other companies. This encouraged companies to drive production costs. IMS described the ratio of foreign suplier sales to total sales. High ratio IMS reduced potential collusion. FDI is the ratio of foreign ownership to total shares in the company. GEO described geography dispersion to measure regional market segmentation; it had a positive impact on profits. In the cost ratio, CDR described the ratio of value added per worker to $50 \%$ of the smallest suppliers to the average value added per worker in $50 \%$ of the largest suppliers. According to Martin (1979), MES was one of the natural entry condition variables which is the average of $50 \%$ firms with the largest output. For ekspor condition, this research used EKS to measure the ratio of total export to total sales. GR in this research described the industry growth demand. This research used the ratio of fixed cost to total sales in the yearly period. The interaction between CR2 and GR was made where both variables could make mutual effect to influence PCM. GP in this research explained dummy variable of Permendag No.21 / 2005 in 2005 that influenced the structure, conduct, and performance. Dummy crisis (DK) is a financial crisis that occurred in the United States, which was given the number 0 in the time before the crisis and 1 after the occurrence of financial crisis in the United States. In mid2007, subprime mortgages became the trigger for the crisis in the country. In September 2008 along with the announcement of the bankruptcy of several major financial institutions in the country. Variables $\mathrm{X}$ and $\mathrm{Y}$ in this research estimated dummy variables for two bigest companies that control the market share. PCM is the ratio of net income to total sales in the company. The research used time lag for CR2, ARS, PCM, CDR, and MES. Time lag described the conditions of last year that was linked to the current year. Acording to Farber (1981), the high company's profit in the previous year became an indicator of the company's monopoly. The increase of concentration in the previous year made the company easily create profits. Advertising and $\mathrm{R} \& \mathrm{D}$ costs led to entry barriers in the next year; so companies could easily earn more profit. Current profitability affected the conduct parameter to create entry barriers in the form of advertising and R \& D in the next year.

\section{ANALYSIS \& RESULTS}

The parameter estimation method in the model applied randomness-Two Stage Least Square (TSLS). The inferential analysis of structure, conduct, and performance relationships is presented in the following table:
Table 1. Output of Simultaneous Equation System

\begin{tabular}{|c|c|c|c|}
\hline PREDETERMINE & CR2 & ARS & PCM \\
\hline INTERCEPT & $\begin{array}{c}0,79351 * * * \\
(19.42257)\end{array}$ & $\begin{array}{c}-5.14394 \\
(-1.13787)\end{array}$ & $\begin{array}{c}5.12127 \\
(1.65264)\end{array}$ \\
\hline CR2 & & $\begin{array}{l}13.07233 \\
(1.17081)\end{array}$ & $\begin{array}{c}-6.15273 \\
(-1.31800)\end{array}$ \\
\hline $\mathrm{CR}^{2}$ & & $\begin{array}{c}-8.08489 \\
(-1.17759)\end{array}$ & \\
\hline ARS & $\begin{array}{c}-0.00307 \\
(-0.04651) \\
\end{array}$ & & $\begin{array}{c}0.74957 \\
(0.32562) \\
\end{array}$ \\
\hline EFF & & & $\begin{array}{c}0.01208 \text { ** } \\
(3.37551)\end{array}$ \\
\hline IMS & & & $\begin{array}{c}-0.42453 \\
(-5.30167)\end{array}$ \\
\hline FDI & $\begin{array}{c}0.00028 \\
(0.04315)\end{array}$ & $\begin{array}{c}-0.03295 \\
(-1.30433)\end{array}$ & $\begin{array}{c}-0.12524 \\
(-1.65821)\end{array}$ \\
\hline GEO & & & $\begin{array}{c}0.08659 \\
(0.52182) \\
\end{array}$ \\
\hline CDR & $\begin{array}{c}-0.08785 * * * * \\
(-8.04978)\end{array}$ & & $\begin{array}{c}0.20627 \\
(1.03052)\end{array}$ \\
\hline MES & $\begin{array}{c}0.00049 \\
(0.37950)\end{array}$ & & $\begin{array}{c}-0.00831 \\
(-0.37161)\end{array}$ \\
\hline EKS & & & $\begin{array}{c}-3.55155 \\
(-1.57924)\end{array}$ \\
\hline KS & & & $\begin{array}{l}0.03414 * \\
(1.94927)\end{array}$ \\
\hline GR x CR2 & & & $\begin{array}{l}6.84668 * \\
(1.68119)\end{array}$ \\
\hline GR & $\begin{array}{l}-0.01876 * \\
(-1.69694)\end{array}$ & $\begin{array}{c}-0.05444 \\
(-1.25726)\end{array}$ & $\begin{array}{l}-5.61887 * \\
(-1.69027)\end{array}$ \\
\hline $\mathbf{C R 2}_{(\mathrm{t}-1)}$ & $\begin{array}{c}0.04447 \\
(1.08971)\end{array}$ & & $\begin{array}{c}0.55337 \\
(0.54197)\end{array}$ \\
\hline $\mathbf{A R S} \mathbf{S}_{(t-1)}$ & $\begin{array}{c}0.03309 \\
(1.60752) \\
\end{array}$ & & $\begin{array}{c}0.25795 \\
(1.20553) \\
\end{array}$ \\
\hline $\operatorname{PCM}_{(t-1)}$ & $\begin{array}{c}-0.01002 \\
(-1.22590)\end{array}$ & $\begin{array}{c}-0.03404 \\
(-1.15975)\end{array}$ & \\
\hline $\operatorname{CDR}_{(t-1)}$ & & & $\begin{array}{c}0.11763 \\
(0.35878)\end{array}$ \\
\hline $\operatorname{MES}_{(t-1)}$ & $\begin{array}{c}-\mathbf{- 0 . 0 0 1 3 7} \\
(-1.08974)\end{array}$ & & \\
\hline DK & $\begin{array}{c}0.09464 * * * \\
(17.72070)\end{array}$ & $\begin{array}{l}0.12855 * \\
(1.72052)\end{array}$ & $\begin{array}{c}-0.07028 \\
(-0.46997)\end{array}$ \\
\hline GP & $\begin{array}{c}0.04555 \text { *** } \\
(7.93140)\end{array}$ & $\begin{array}{c}0.00298 \\
(0.10669)\end{array}$ & $\begin{array}{c}-0.14542 \\
(-1.47194)\end{array}$ \\
\hline $\mathbf{X}$ & $\begin{array}{c}0.00379 \\
(0.40903)\end{array}$ & $\begin{array}{c}-0.03333 \\
(-1.37156)\end{array}$ & $\begin{array}{c}0.11349 \\
(0.59417)\end{array}$ \\
\hline $\mathbf{Y}$ & $\begin{array}{c}0.00224 \\
(0.32005)\end{array}$ & $\begin{array}{c}-0.01304 \\
(-0.53889)\end{array}$ & $\begin{array}{c}0.07848 \\
(0.78525)\end{array}$ \\
\hline $\mathbf{R}^{2}$ & 0.91661 & 0.15375 & 0.50242 \\
\hline $\mathbf{R}^{2}$ Adj & 0.90757 & 0.09232 & 0.41948 \\
\hline$D f$ & 120 & 124 & 114 \\
\hline
\end{tabular}

indicates statistical significant at the level of $5 \%$; and $*$ indicates statistical significant at the level of $10 \%$.

The analysis result on the structure explained that when the average value added per worker ratio of $50 \%$ of the smallest suppliers to the average value added per worker of $50 \%$ of the largest suppliers (CDR) increased by one, then the average decrease of CR2 was equal to 0,08785 , ceteris paribus. 
Another influential factor is GR which indicated an average decrease of CR2 of 0.01876 when the ratio of demand over the previous year (GR) increased by twice the previous year, ceteris paribus. The study explained that there was an average increase of CR2 of 0.09464 after the financial crisis that occurred in the United States. The central bank's policy "The Fed" made interest rates almost zero percent when a crisis happened in the United States. This brought a problem to investors in getting enough returns by depositing the money. As a result, they transfered the money to other countries in order to get higher return than to let the money saved in the country. In addition to the crisis, there was also an average increase of CR2 of 0.04555 after the regulation of Permendag No.21 / 2005 in 2005, ceteris paribus. An increase of advertising cost and $\mathrm{R} \& \mathrm{D}$ ratio to production cost of 0.12855 existed post the financial crisis in United States, ceteris paribus. This affected positively especially on advertising costs because the motorcycle industry in Indonesia focused the competition on advertising.

EFF, IMS, GR, KS, and GRxCR2 are the significant variables in the model of performance equation. In this model, there was a significant increase in the average net income to total sales (PCM) ratio of 0.01208 when the ratio of value added to input (EFF) increased by two times, ceteris paribus. This happened to the motorcycle industry in Indonesia, since it is classified into full-technology industry. Similarly to IMS, there was a decrease in the average net income to total sales (PCM) ratio of 0.42453 when the ratio of import to sales (IMS) increased by one, ceteris paribus. GRxCR2 showed an interaction between industrial demand growth and CR2; there was an increase in the average net income to total sales (PCM) ratio of 6.84668 when the interaction increased by one unit. Interactions between industrial demand growth and company ratio concentration meant that firms with such high concentration could increase the ratio of net income to total sales by utilizing the growth of motorcycle industry demand in Indonesia.

This study proves empirically that the existence of Permendag No.21/2005 in 2005 has a significant positive effect on CR-2 (model structure), meaning that the existence of the policy has made the competition in the motorcycle industry in Indonesia become uncompetitive. The simultaneous model analysis showed that the Permendag indirectly affected PCM. The Permendag directly gave significant positive influence to CR-2, which then made the interaction between CR-2 and industrial demand growth positively affected the PCM significantly. Other variables affecting the structure are dummy crisis, demand industry growth, and cost disadvantage ratio; other variables affecting conduct are dummy crisis and foreign direct investment, while other variables affecting performance are company efficiency, export and import ratio to sales, the company's capital ratio to sales, and the growth of industrial demand.
In 2005, the Ministry of Trade revised the Decree of the Minister of Trade and Cooperatives No. 75 / KP / I / 83 dated January 25, 1983 on compulsory registration of trade / association organizations in Indonesia. This made the association membership unnecessary. Pro-competitive improvement expectations were addressed when the company ran its own business without the communication and coordination among the company's stakeholders in the forum conducted by the association. This made the dominant market shareholders companies in the industry more exclusive and often rejected the prospective member companies who wanted to join the association. This is contradictory when the members who were the dominant market shareholders in the motorcycle industry exclusively coordinated and potentially were easy to deal. This was possible because the four largest market share powers were listed as AISI members.

\section{References}

[1] Arsyad and Kusuma (2014). Ekonomika Industri (Pendekatan Struktur, Perilaku, dan Kinerja). Yogyakarta : UPP STIM YKPN.

[2] Atmodjo (1997).Analisa Industri Sepeda Motor di Indonesia. Tesis Tidak Dipublikasikan Magister Perencanaan dan Kebijakan Publik Fakultas Ekonomi Universitas Indonesia, Depok

[3] Baye, Michael R. (2010). Managerial Economics and Business Strategy, 5th edition. New York : Mc Graw-Hill.

[4] Clarke, Roger (2003). Industrial Economics. Oxford : Blackwell Publishers.

[5] Dorfman R and Steiner P.O. (1954). Optimal Advertising and Optimal Quality. American Economic Review 44, 826 - 836.

[6] Farber Stephen (1981), Buyer Market Structure and R\&D Effort : A Simultaneous Equations Model. The Review of Economics and Statistics. Vol.63 No.3. 336-345.

[7] Gaskins, D. (1971). Dynamic Limit Pricing : Optimal Policies under Threat of Entry. Journal of Economic Theory. Vol.3. 306-322.

[8] Haryotejo (2006). Analisis Persaingan Usaha Dikaitkan dengan Hambatan Masuk pada Industri Sepeda Motor Indonesia. Tesis Tidak Dipublikasikan Magister Perencanaan dan Kebijakan Publik Fakultas Ekonomi Universitas Indonesia, Depok.

[9] Lustgarden S.R. (1975). The Impact of Buyer Concentration in Manufacturing Industry. Review of Economics and Statistics. Vol.57 No.2 . $125-132$.

[10] Martin Stephen (1979). Advertising, Concentration, and Profitability : The Simultaneity Problem. The Bell Journal of Economics. Vol. 10, 639-647.

[11] Pradiptyo, Rinawan (1996). Dampak Kebijakan Sektor Riil Terhadap Struktur dan Kinerja Struktur Industri Indonesia Tahun 1980-1994. Jurnal Kelola Universtias Gadjah Mada Business Review No. 11/V/96, h. $34-52$.

[12] Setiawan ( 2006). Analisis Hubungan Antara Struktur, Perilaku, dan Performansi Industri di Indonesia. Discussion Paper. Laboratorium Penelitian, Pengabdian pada Masyarakat dan Pengkajian Ekonomi (LP3E) Fakultas Ekonomi Universitas Padjadjaran.

[13] Strickland and Weiss (1976). Advertising, Concentration, and Price-Cost Margins. The Journal of Political Economy. 84 No.5, 1109-1122.

[14] Yucheng et al.(2015). Empirical Study on The Relationship Between Market Share, Advertising Density and Ratio of Sales. Journal of Food Technology Research. 2(1), 11-20. 